\title{
ANALISIS MEKANISME PEMUNGUTAN DAN EFEKTIVITAS RETRIBUSI PASAR DI KOTA BITUNG
}

\author{
Meivi M. Kaunang ${ }^{1}$, Lintje Kalangi ${ }^{2}$, Tressje Runtu ${ }^{3}$ \\ ${ }^{1,2,3}$ Fakultas Ekonomi dan Bisnis, Jurusan Akuntansi, Universitas Sam Ratulangi, Jl.Kampus Bahu. Manado, \\ 95115, Indonesia
}

Email : kaunangmeivi@yahoo.com

\begin{abstract}
One source of Regional Original Revenue is local taxes, regional levies and other legitimate local revenue management. Regional levies consist of 3 types of retribution, namely general service retribution, business service retribution and certain licensing retribution. Market's levies is one type of regional retribution that is included in general retribution whose collection must be in accordance with the existing operational procedure standards to support the realization of its acceptance. This study aims to determine the mechanism of market's levies collection and the level of effectiveness of market's levies in the city of Bitung. The research method used is qualitative descriptive analysis, by analyzing the collection mechanism and the effectiveness of market's levies. The results of the study show that the mechanism of collection of retribution is in accordance with the existing SOP and the achievement of its effectiveness is effective with an average level of $87.13 \%$. Bitung city government can be better able to approach marketers for example by socializing market's levies regulations so that later can also support the realization of levies revenue.
\end{abstract}

Keywords : Market's Levies, Collection Mechanisms and Effectiveness

\section{PENDAHULUAN}

Kemandirian suatu daerah bisa dilihat dari penerimaan daerah, semakin besar Pendapatan Asli Daerah mengindikasikan bahwa daerah tersebut mampu dan berkurangnya ketergantungan terhadap pemerintah pusat. Pendapatan Asli Daerah tentunya memberikan pengaruh yang cukup tinggi untuk kegiatan atau pertumbuhan daerah diberbagai sektor khususnya disektor pembangunan yang menjadi tolak ukur yang penting karena pembangunan secara fisik merupakan hal langsung yang bisa di lihat atau dinikmati oleh masyarakat tapi pembangunan di sektor kesehatan, pendidikan dan lain-lain harus di perhatikan juga karena itu juga mendorong pembangunan ekonomi dalam hal sumber daya manusia. Pendapatan daerah bisa berasal dari pajak daerah, retribusi daerah dan sumber pendapatan lain yang sah.

Salah satu hal juga yang menunjang pendapatan adalah retribusi daerah sebagai potensi yang harus diperhatikan agar bisa meningkatkan penerimaan daerah dan pengelolaan daerah tersebut. Undang-undang Republik Indonesia Nomor 28 Tahun 2009 menyatakan bahwa Retribusi Daerah yang selanjutnya disebut Retribusi, adalah pungutan daerah yang disediakan atau diberikan oleh Pemerintah Daerah untuk kepentingan orang pribadi atau badan untuk pembayaran atas jasa atau pemberian izin tertentu. Ada beberapa jenis Retribusi daerah menurut Undang-undang No 28 tahun 2009 yaitu jasa umum, jasa khusus dan perizinan tertentu. Tujuan dari retribusi daerah ini sama dengan pemungutan pajak daerah yang dilakukan oleh pemerintah setempat yang tujuannya untuk memenuhi kas Negara atau daerah dalam rangka untuk mencukupi kebutuhan daerah dan untuk mensejahterahkan masyarakat secara langsung.

Retribusi Pasar merupakan salah satu dari jenis retribusi daerah yaitu termasuk dalam retribusi umum. Retribusi Pasar adalah penyediaan fasilitas pasar yang dikelola oleh 
pemeritah daerah dan disediakan untuk pedagang untuk fasilitas pasar tradisional atau sederhana berupa pelataran, los dan kios (UU No.28 Tahun 2009). Untuk Pemerintah Daerah, Retribusi Pasar merupakan suatu hal yang penting dikarenakan menjadi salah satu sumber dari Pendapatan Asli Daerah untuk memenuhi kebutuhan daerah agar daerah tersebut tidak bergantung lagi terhadap pemerintah pusat. Retribusi Pasar yang merupakan retribusi daerah ini, mempunyai potensi yang sangat bagus untuk pendapatan daerah maka pemerintah daerah harus bisa memanfaatkan potensi yang ada untuk meningkatkan penerimaan retribusi. Retribusi Pasar memiliki peran untuk pemerintah daerah dalam penerimaannya, untuk mendorong peningkatan retribusi pasar ini maka pemerintah harus melakukan pembangunan, penataan dan perluasan untuk kemajuan penerimaan retribusi. Pemerintah tentu mempunyai target yang telah ditetapkan untuk penerimaan retribusi pasar ini. Dalam target yang sudah ditetapkan tentunya terdapat realisasi penerimaan retribusi pasar tersebut maka peneliti ingin melihat bagaimana mekanisme pemungutan yang ditetapkan untuk penerimaan retribusi pasar.

Dalam penelitian ini melihat bagaimana mekanisme pemungutan yang digunakan untuk pasar yang ada dikota bitung apakah sudah sesuai dengan SOP dan juga ingin mengetahui bagaimana efektivitas retribusi pasar di kota bitung apakah sudah efektif atau tidak dalam peningkatan penerimaan retribusi pasar. Dalam pengelolaan retribusi pasar di Kota Bitung Dinas Perdagangan merupakan lembaga pemerintah yang diberi wewenang untuk mengelola retribusi pasar yang ada,. Posisi geografis Kota Bitung yang strategis serta dengan kondisi alam laut yang menguntungkan baik untuk wisatawan atau nelayan dan kondisi topografi berbukit yang dijadikan kawasan pertanian, perkebunan dan lain-lain menjadi salah satu sumber pendapatan dari penduduk sehingga bisa meningkatkan kondisi perekonomian yang ada di Kota Bitung, yang hasil pertanian ataupun perkebunan bisa di perjualbelikan di pasar setempat. Bila Pemerintah Daerah bisa memaksimalkan potensi yang ada maka bisa memberikan peningkatan serta dampak dalam kemajuan dan pembangunan daerah terutama untuk pembangunan dan pengolaan retribusi pasar serta sumbangsihnya terhadap PAD. Untuk memenuhi hal itu Pemerintah harus bisa melakukan perbaikan dalam pemungutan retribusi agar bisa dikelola secara baik.

\section{TINJAUAN PUSTAKA}

Akuntansi Pajak. Akuntansi pajak merupakan suatu proses penyesuaian laporan keuangan berdasarkan ketentuan perpajakan yang menghasilkan laporan keuangan fiskal. Menurut American accounting association, akuntansi adalah proses penilaian pengukuran, mengidentifikasi dan melaporkan informasi ekonomi untuk pengambilan keputusan yang tegas dan jelas bagi para pihak yang menggunakan informasi (Pura, 2013:4).

Pajak. Menurut Waluyo (2013 : 3) Pajak adalah iuran wajib berdasarkan norma hukum berupa uang atau barang yang dipungut oleh penguasa, dalam mencapai kesejahteraan dengan menutup biaya produksi barang-barang dan jasa-jasa kolektif.

Pajak Daerah. Menurut Undang-Undang Republik Indonesia Nomor 28 tahun 2009 Pasal 1 ayat 10 Pajak Daerah merupakan kontribusi yang wajib kepada Daerah dan terutang oleh orang pribadi atau badan bersifat secara memaksa berdasarkan Undang-Undang, dengan tidak mendapatkan imbalan secara langsung dan digunakan untuk keperluan Daerah bagi sebesarbesarnya kemakmuran rakyat.

Retribusi Daerah. Retribusi menurut UU No. 28 tahun 2009 adalah pungutan daerah yang disediakan atau diberikan oleh Pemerintah Daerah untuk kepentingan orang pribadi atau badan untuk pembayaran atas jasa atau pemberian izin tertentu. Retribusi ini berbeda dengan Pajak Penghasilan atau Pajak Pertambahan Nilai yang langsung dikelola oleh Direktorat jenderal Pajak, retribusi ini yang bisa disebut juga sebagai pajak daerah dikelola oleh Dinas Pengelolaan Pajak Dan Retribusi Daerah. 
Tata Cara Pemungutan Retribusi. Tata cara pemungutan retribusi menurut Undang-undang Nomor 28 Tahun 2009 adalah sebagai berikut :

1. Retribusi dipunggut dengan menggunakan kupon, karcis dan kartu langganan berdasarkan SKRD (Surat Ketetapan Retribusi Daerah) atau dokumen lain yang dipersamakan

2. Yang kurang bayar atau tidak membayar pada waktunnya dikenakan sanksi administratif 2\% per bulan dengan menggunakan STRD (Surat Tagihan Retribusi Daerah).

3. Peraturan kepala daerah yang menentukan tata cara pemungutan retribusi.

Prinsip dan sasaran penetapan tarif retribusi. Prinsip dan sasaran penetapan tarif retribusi menurut Mardiasmo (2018 : 21) sebagai berikut :

1. Retribusi Jasa Umum, ditetapkan dengan memperhatikan biaya, biaya yang dimaksud yaitu biaya operasi dan pemeliharaan, biaya bunga dan biaya modal untuk penyediaan jasa yang bersangkutan, aspek keadilan, kemampuan masyarakat dan efektivitas pengendalian atas pelayanan tersebut.

2. Retribusi Jasa Usaha, keuntungan yang layak merupakan tujuan dan dasar yang dapat diperoleh apabila pelayanan jasa telah di lakukan secara efisien dan berorientasi pada harga pasar.

3. Retribusi Perizinan Tertentu, biaya penyelenggaraan pemberian izin meliputi penerbitan dokumen izin, pengawasan dilapangan, penegakan hukum, penatausahaan, dan biaya dampak negatif dari pemberian izin tersebut. Biaya ini didasarkan pada tujuan untuk menutup sebagian atau seluruh biaya penyelenggaraan pemberian izin yang bersangkutan.

Retribusi Pasar. Retribusi Pasar adalah merupakan merupakan salah satu dari jenis retribusi daerah yaitu termasuk dalam retribusi umum. Sesuai Perda Kota Bitung No. 4 Tahun 2011 disebut Retribusi Pelayanan Pasar dipunggut Retribusi atas penyediaan fasilitas pasar tradisional atau sederhana oleh pemerintah yang khusus disediakan untuk pedagang yang berupa berupa kios, pelataran, los. Pasar atau pasar tradisional yang dikelola oleh pemerintah daerah adalah area tempat jual beli barang dan atau jasa melalui proses tawar menawar dengan jumlah penjual lebih dari satu dan tempat usaha berupa kios, los dan pelataran.

\section{Standar Operasional Prosedur Penerimaan Retribusi Pasar di Kota Bitung}

\begin{tabular}{|c|c|c|c|c|c|c|c|c|c|}
\hline \multirow[b]{2}{*}{ No } & \multirow[b]{2}{*}{ Uraian Prosedur } & \multirow[b]{2}{*}{$\begin{array}{l}\text { Kepala Seksi } \\
\text { Perizinan } \\
\text { Pendaftaran } \\
\text { Perusahaan dan } \\
\text { Opersional Pasar }\end{array}$} & \multirow[b]{2}{*}{$\begin{array}{l}\text { Kepala } \\
\text { Pasaf }\end{array}$} & \multirow[b]{2}{*}{ Penagih } & \multirow[b]{2}{*}{ Pedagang } & \multirow[b]{2}{*}{ Bendahara } & \multirow[b]{2}{*}{ Bank } & \multicolumn{2}{|c|}{ Mutu Kerja } \\
\hline & & & & & & & & Persyaratan & Waktu \\
\hline 1 & $\begin{array}{l}\text { Kepala pasar mengambil } \\
\text { karcis melalui seksi } \\
\text { perizinan, pendaftaran } \\
\text { perusahaan dan } \\
\text { operasional pasar }\end{array}$ & & & & & & & kendaraan & $\begin{array}{l}10-20 \\
\text { menit }\end{array}$ \\
\hline 2 & $\begin{array}{l}\text { Kepala pasar } \\
\text { memberikan karcis ke } \\
\text { penagih retribusi }\end{array}$ & & & & & & & -karcis & $\begin{array}{l}5 \\
\text { menit }\end{array}$ \\
\hline 3 & $\begin{array}{l}\text { Penagih melakukan } \\
\text { penagihan pada setiap } \\
\text { pedagang berdasarkan } \\
\text { nominal karcis }\end{array}$ & & & & & & & $\begin{array}{l}\text {-karcis } \\
\text {-uang }\end{array}$ & $\begin{array}{l}6-8 \\
\text { jam }\end{array}$ \\
\hline 4 & $\begin{array}{l}\text { Retribusi selanjutnya } \\
\text { diserahkan oleh penagih } \\
\text { kepada kepala pasar }\end{array}$ & & & & & & & -uang & $\begin{array}{l}10 \\
\text { menit }\end{array}$ \\
\hline 5 & $\begin{array}{l}\text { Kepala pasar menyetor } \\
\text { ke bendahara penerima }\end{array}$ & & & & & & & $\begin{array}{l}\text {-ATK } \\
\text {-uang }\end{array}$ & $\begin{array}{l}10-20 \\
\text { menit }\end{array}$ \\
\hline 6 & $\begin{array}{l}\text { Bendahara penerima } \\
\text { menghitung, lalu } \\
\text { menyetor retribusi ke } \\
\text { Bank, selanjutnya slip di } \\
\text { arsip }\end{array}$ & & & & & & & $\begin{array}{l}\text {-ruang } \\
\text { tertutup } \\
\text {-kendaraan } \\
\text {-slip setor } \\
\text {-ATK }\end{array}$ & $\begin{array}{l}1-2 \\
\text { jam }\end{array}$ \\
\hline
\end{tabular}

Sumber: Dinas Perdagangan, 2018/

Gambar 1. SOP penerimaan Retribusi Pasar di Kota Bitung 
Efektivitas. Efektivitas terkait dengan hasil sesungguhnya di capai dengan hasil yang diterapkan (Mahmudi, 2015:86). Menurut Rahardjo (2011 :170) efektivitas ialah keadaan atau kondisi dimana tercapainya suatu tujuan yang diinginkan dengan hasil yang memuaskan melalui penggunaan sarana dan peralatan untuk pencapaian tujuan tersebut.

Penelitian Terdahulu. Naleng (2017) dengan judul "Analisis Potensi dan Efektivitas Pemungutan Retribusi Pasar di Kabupaten Kepulauan Siau Tagulandang" tujuan dari penelitian ini untuk menganalisis dan mengetahui potensi dan efektivitas retribusi pasar di kabupaten kepulauan siau tagulandang biaro. Metode penelitian yang digunakan adalah kualitatif. Hasil penelitian menunjukkan bahwa Potensi retribusi pasar pendapatannya sangat besar dan Tingkat efektivitas pemungutan retribusi pasar tahun 2014-2016 adalah efektif. Ini dilihat dari rata-rata efektifitas pemungutan retribusi pasar jenis kios mencapai 97,57\% dan retribusi pasar jenis los mencapai 116,83\%. Persamaan penelitian ini dengan penelitian yang dilakukan adalah tentang efektivitas retribusi pasar sedangkan perbedaannya terletak pada objek penelitian. Najoan (2016) dengan judul "Analisis Sistem Pemungutan dan Penyetoran Retribusi Pasar Pada Dinas Perindustrian Perdagangan Koperasi dan Penanaman Modal Kota Kotamobagu" tujuan dari penelitian ini Untuk menganalisis sistem penerimaan retribusi pasar. Metode yang digunakan adalah kualitatif. Hasil penelitian menunjukkan Sistem dalam pemungutan retribusi telah memadai karena unsur yang ada pada hasil penelitian terdapat juga pada teori pengendalian internal. Persamaan dengan penelitian yang dilakukan adalah tentang retribusi pasar sedangkan perbedaannya terletak pada objek penelitian.

\section{METODE PENELITIAN}

Jenis Penelitian. Jenis penelitian yang digunakan adalah penelitian kualitatif yang bersifat deskriptif dan cenderung menggunakan analisis. Penelitian kualitatif menghasilkan data deskriptif berupa perilaku orang yang diamati atau dapat berupa ucapan. (Sujarweni, 2015:21).

Tempat serta Waktu Penelitian. Penelitian ini dilaksanakan pada kantor Dinas Perdagangan Jln Wolter Monginsidi No. 85 Kel. Wangurer Barat Kec. Madidir Kota Bitung. Waktu penelitian dilaksanakan pada bulan Agustus sampai September tahun 2018.

Jenis Data Penelitian. Jenis Data Penelitian yang digunakan dalam penelitian ini yaitu data kualitatif dan data kuantitatif.

1. Data kualitatif dalam penelitian ini adalah data deskriptif dalam bentuk uraian hasil wawancara dengan pimpinan atau pegawai di kantor Dinas Perdagangan mengenai mekanisme pemungutan retribusi pasar di Kota Bitung.

2. Data kuantitatif dalam penelitian ini berupa data yang di dapat dari laporan realisasi dan target Retribusi Pasar yang ada di Kota Bitung.

Sumber Data. Sumber data dalam penelitian ini adalah data primer dan data sekunder. Menurut Sujarweni (2015 : 89) Sumber data terbagi atas dua bagian yaitu :

1. Data Primer. Data primer yaitu data yang di berikan secara langsung dari sumber data kepada pengumpul data. Data primer di dalam penelitian ini adalah data atau informasi yang diperoleh dari hasil wawancara atau tanya jawab mengenai mekanisme pemungutan, kendala dalam pemungutan serta bagaimana mengatasi masalah tersebut yang di dapatkan langsung dari instansi terkait.

2. Data Sekunder. Data sekunder merupakan sumber yang tidak secara langsung memberi data pada pengumpul data. Data sekunder dalam penelitian ini adalah data yang di sajikan dalam bentuk angka dalam rupa target dan realisasi dari Retribusi Pasar di Kota Bitung.

Metode Pengumpulan Data. Dalam penelitian ini metode pengumpulan data yang digunakan adalah sebagai berikut: 
1. Metode wawancara, yakni dengan melakukan wawancara dengan seksi perizinan, pendaftaran dan operasional pasar yang berhubungan dengan mekanisme pemungutan retribusi pasar di Kota Bitung.

2. Metode dokumentasi, yakni dengan melalui pencatatan dan fotocopy data yang diperlukan. Data yang di maksud dalam penelitian ini adalah gambaran umum objek, laporan realisasi dan target retribusi pasar untuk tahun 2013-2017 di Kota Bitung.

Metode Analisis. Metode yang digunakan adalah metode deskriptif, yaitu penelitian dengan metode pembahasan permasalahan yang sifatnya menerangkan serta menguraikan suatu keadaan yang ada agar mendapatkan gambaran yang lebih rinci mengenai keadaan yang sebenarnya terjadi sehingga bisa menganalisa masalah yang ada. Penelitian ini menggunakan analisis efektivitas untuk memberikan gambaran mengenai efektivitas retribusi pasar di Kota Bitung.

Analisis Efektivitas. Analisis efektivitas adalah analisa hubungan antara realisasi terhadap target yang memungkinkan apakah besarnya penerimaan sesuai dengan target yang ada. Efektivitas dapat dihitung dengan rumus sebagai berikut :

$$
\text { Efektifitas }=\frac{\text { Realisasi }}{\text { Target }} \times 100 \%
$$

Dalam menilai tingkat efektivitas digunakan kriteria yang di sajikan pada Tabel 1.

Tabel 1. Klasifikasi Nilai Efektivitas

\begin{tabular}{ll}
\hline \multicolumn{1}{c}{ Presentase } & Kriteria \\
\hline $100 \%$ keatas & Sangat Efektif \\
$90 \%-100 \%$ & Efektif \\
$80 \%-90 \%$ & Cukup Efektif \\
$60 \%-80 \%$ & Kurang Efektif \\
Di bawah $60 \%$ & Tidak Efektif \\
\hline
\end{tabular}

Sumber : Depdagri, Kepmendagri No. 690.900.327 tahun 1996 (Naleng 2017)

\section{HASIL PENELITIAN DAN PEMBAHASAN}

\subsection{Hasil Penelitian}

Dengan terbitnya Peraturan Daerah Nomor 8 Tahun 2016 tentang Pembentukan dan Susunan Perangkat Daerah Kota Bitung menjadikan beberapa Dinas yaitu Dinas Pasar, Dinas Energi dan Sumber Daya Mineral serta Dinas Perindustrian dan Perdagangan telah bergabung menjadi Dinas Perdagangan Kota Bitung sehingga Pendapatan Asli Daerah dari Dinas Pasar serta Dinas Energi dan Sumber Daya Mineral, dikelola oleh Dinas Pedagangan Kota Bitung pada tahun 2017. Dinas Perdagangan sekarang mengelola beberapa jenis pendapatan yaitu Retribusi Pasar, Kebersihan Pasar, Pengguna Fasilitas Parkir di Pasar, Retribusi Dokumen Menempati Bangunan Kios, Tera dan Tera Ulang. Berdasarkan dengan hasil wawancara dengan ibu Welmi Kalangi selaku seksi perizinan, pendaftaran perusahaan dan operasional pasar Ada 3 (tiga) pasar yang di punggut retribusi oleh Dinas Perdagangan yakni pasar winenet, pasar girian dan pasar cita. Di pasar cita terbagi menjadi 2 jenis pasar yaitu pasar jajan dan kanopi. Struktur dan besarnya tarif Retribusi Pasar di Kota Bitung disesuaikan dengan Perda Kota Bitung Nomor 1 Tahun 2014. Penetapan tarif berdasarkan jenis fasilitas yang terdiri dari luas lokasi, halaman/pelataran, kios, los, jangka waktu pemakaian dan jasa kebersihan. Ada pembagian masa Retribusi untuk Retribusi Pelayanan Pasar yaitu pertahun, perbulan dan per hari.

Mekanisme Pemungutan Retribusi Pasar di Kota Bitung. Sesuai dengan hasil wawancara dengan ibu Welmi Kalangi selaku Kepala Seksi Perijinan, Pendaftaran 
Perusahaan dan Operasional Pasar yang bertanggung jawab terhadap pemungutan Retribusi Pasar pada Dinas Perdagangan Kota Bitung mengenai bagaimana mekanisme pemungutan Retribusi Pasar di Kota Bitung ibu Welmi mengatakan sebagai berikut :

"Prosedur Pemungutan penerimaan retribusi pasar di Kota Bitung dilaksanakan oleh kolektor yang merupakan staf maupun tenaga kontrak yang bekerja pada Dinas Perdagangan Kota Bitung yang berkoordinasi langsung dengan kepala pasar masing masing untuk memungut retribusi. Karcis di ambil kepada kepala seksi perijinan, pendaftaran perusahaan dan operasional pasar. Pemungutannya dilaksanakan setiap hari dan disetorkan kepada bendahara penerima untuk kemudian di setor ke Bank SulutGO”.

Hasil wawancara dengan ibu welmi di pasar winenet juga ada ruko yang di kelola oleh pemerintah daerah namun di pasar cita dan pasar girian tidak ada ruko dan kolektor hanya memungut retribusi dari pedagang. Untuk pemungutan masa retribusi pertahun di tagih pada saat tanggal jatuh tempo tapi di lapangan biasanya para pedagang membayar mendekati akhir tahun dan pemungutan bulanan dipunggut perbulan namun banyak juga pedagang yang membayar pada bulan-bulan terakhir. Pemungutan retribusi pasar ada tata cara atau standar operasional prosedur dalam pemerimaan retribusi pasar di Kota Bitung dapat di lihat pada Gambar 1. Sesuai juga dengan hasil wawancara yang di lakukan maka di dapatkan data mengenai jumlah pedagang yang ada di 3 (tiga) pasar di kota bitung yang dapat dilihat pada Tabel 2.

Tabel 2. Jumlah Pedagang

\begin{tabular}{|c|c|c|}
\hline No & Pasar & Jumlah Pedagang \\
\hline 1. & Winenet & 542 \\
\hline 2 & Ruko & 89 \\
\hline 3 & Cita & 296 \\
\hline 4. & Girian & 467 \\
\hline & Jumlah & 1.394 \\
\hline
\end{tabular}

Sumber : Dinas Perdagangan Kota Bitung,2018

Hasil wawancara yang di lakukan dengan ibu welmi mengenai kendala yang di hadapi dalam pemungutan di lapangan bahwa :

"Ada beberapa pedagang yang tidak membayar sesuai peraturan atau hanya membayar setengah dari kewajiban yang harus di bayar oleh pedagang" masalah yang didapati juga dalam pemungutan yaitu kolektor mengalami kesulitan dalam penagihan dikarenakan status tanah pedagang yang berada di dekat pasar dan pedagang tidak mau membayar retribusi karena menganggap bahwa mereka berjualan di area tanah milik mereka sendiri."

Berdasarkan juga dengan hasil wawancara mengenai kendala yang dihadapi, timbul pertanyaan dari penulis bagaimana cara mengatasi kendala itu ibu welmi mengatakan :

"Para kolektor biasanya mengambil pendekatan pribadi dengan pedagang" pendekatan yang di lakukan oleh kolektor biasanya menjalin keakraban dan secara tidak langsung kolektor bisa menjelaskan tentang pemungutan retribusi yang dipunggut sehingga pedagang bisa mengerti dan memahami mengapa mereka ditagih atau dipunggut retribusi pasar."

Perhitungan Efektivitas Retribusi Pasar. Berikut ini merupakan laporan target dan realisasi Retribusi Pasar di Kota Bitung dari tahun 2013 sampai 2017 dapat di lihat pada Tabel 3. 
Tabel 3. Target dan Realisasi Retribusi Pasar di Kota Bitung tahun 2013- 2017

\begin{tabular}{|c|c|c|}
\hline Tahun & Target & Realisasi \\
\hline 2013 & 1.350 .000 .000 & 1.100 .375 .300 \\
\hline 2014 & 1.300 .000 .000 & 1.324 .406 .250 \\
\hline 2015 & 1.500 .000 .000 & 1.500 .563 .800 \\
\hline 2016 & 2.500 .000 .000 & 1.456 .188 .500 \\
\hline 2017 & 2.000 .000 .000 & 1.999 .952 .550 \\
\hline
\end{tabular}

Sumber : PAD Kota Bitung, 2018

Dengan rumus efektivitas sebagai berikut :

$$
\text { Efektifitas }=\frac{\text { Realisasi }}{\text { Target }} \times 100 \%
$$

1 Tahun $2013=\frac{1.100 .375 .300}{1.350 .000 .000} \times 100 \%=81,51 \%$

2 Tahun $2014=\frac{1.324 .406 .250}{1.300 .000 .000} \times 100 \%=101,88 \%$

3 Tahun $2015=\frac{1.500 .563 .800}{1.500 .000 .000} \times 100 \%=100,04 \%$

4 Tahun $2016=\frac{1.456 .188 .500}{2.500 .000 .000} \times 100 \%=58,25 \%$

5 Tahun $2017=\frac{1.999 .952 .550}{2.000 .000 .000} \times 100 \%=100 \%$

\subsection{Pembahasan}

Analisis Mekanisme Pemungutan. Dari hasil penelitian yang di lakukan pada Dinas Perdagangan, penerimaan retribusi pasar di Kota Bitung sudah baik dan sesuai dengan Standar Operasional Prosedur di sajikan pada Gambar 1. Mekanisme pemungutannya dimulai dari kepala pasar mengambil karcis kepada seksi perizinan, pendaftaran perusahaan dan operasional pasar yang di ambil pada kantor Dinas Perdagangan, dan kepala pasar memberikan karcis tersebut kepada penagih kemudian akan di tagih retribusi kepada pedagang biasanya di tagih pada pagi hari, setelah dilakukan penagihan para kolektor memberikan hasil tagihan kepada kepala pasar dan kepala pasar menghitung lalu membawa hasil pemungutan dan menyetornya kepada bendahara penerima retribusi pasar di Dinas Perdagangan.

Setelah menyetorkan hasil retribusi dari setiap pasar yang ada, bendahara penerima lalu kemudian menghitung, membawa ke bank menyetor retribusi ke Bank SulutGO yang ada kemudian bank sulut akan memberikan bukti slip penyetoran yang harus disimpan atau diarsip oleh bendahara penerima. Dari setiap tahap yang dilakukan dibutuhkan persyaratan agar bisa menunjang penerimaan retribusi yang ada yaitu seperti kendaraan, uang, alat tulis dan lain-lain sesuai dengan kebutuhan yang di perlukan. Terdapat juga pembagian waktu agar penerimaan retribusi bisa efektiv dan tidak memakan banyak biaya. Penagihan ini dilakukan perhari, ada juga yang dilakukan pertahun sesuai tanggal jatuh tempo walaupun pedagang 
biasanya membayar pada akhir tahun dan perbulan dipunggut bulanan tapi juga pada kenyataannya banyak juga yang membayar mendekati bulan-bulan terakhir.

Analisis Efektivitas Retribusi Pasar di Kota Bitung

Tabel 4. Efektivitas Retribusi Pasar di Kota Bitung

Tahun 2013 - 2017

\begin{tabular}{ccl}
\hline Tahun & Efektivitas Retibusi Pasar di Kota Bitung (Presentase) & Kriteria \\
\hline 2013 & $81,51 \%$ & Cukup Efektif \\
2014 & $101,88 \%$ & Sangat Efektif \\
2015 & $100.04 \%$ & Sangat Efektif \\
2016 & $58.25 \%$ & Tidak Efektif \\
2017 & $100.00 \%$ & Sangat Efektif \\
\hline
\end{tabular}

Sumber : Hasil Olahan (2018)

Efektivitas Retribusi Pasar di Kota Bitung menunjukan bahwa pemungutan dan pengelolaan retribusi pasar di Kota Bitung sudah cukup efektif pada tahun 2013 meskipun belum mencapai kriteria yang di inginkan namun pada tahun 2014 dan 2015 mengalami peningkatan dan di nilai sangat efektif karena sudah mencapai dan melebihi kriteria yang ada, pada tahun 2016 terjadi penurunan dan di nilai tidak efektif di karenakan target yang di tentukan pemerintah terlalu tinggi sedangkan pada realisasi penerimaan yang di dapatkan cukup kurang atau tidak efektif, pada tahun 2017 terjadi kenaikan ulang di karenakan realisasi penerimaan sudah bisa mencapai ulang target yang di tentukan oleh pemerintah dan di nilai sangat efektif.

\section{KESIMPULAN DAN SARAN}

\subsection{Kesimpulan}

Berdasarkan pembahasan maka kesimpulan penelitian ini adalah :

1. Mekanisme pemungutan yang dilaksanakan oleh Dinas Perdagangan sudah sesuai dengan Standar Operasional Prosedur yang ada dan ternyata mampu menunjang penerimaan realisasi retribusi pasar.

2. Hasil perhitungan efektivitas retribusi pasar menunjukan bahwa pemungutan retribusi pasar di Kota Bitung sudah efektif walaupun pada tahun 2013 belum cukup efektif tapi pada tahun 2014 dan 2015 mencapai sangat efektif namun menjadi tidak efektif lagi pada tahun 2016, dan kembali lagi naik menjadi efektif pada tahun 2017. Pencapaian efektivitas penerimaan retribusi pasar di Kota Bitung mencapai rata-rata $87.13 \%$ sehingga dapat disimpulkan bahwa realisasi penerimaan retribusi pasar sudah efektif.

\subsection{Saran}

Berdasarkan penelitian yang sudah dilaksanakan pada Dinas Perdagangan Kota

Bitung serta memperhatikan kesimpulan yang ada, maka saran yang dapat diberikan yaitu :

1. Pemerintah Kota Bitung dalam hal ini Dinas Perdagangan dapat melakukan pendekatan dengan para pedagang yang bisa di lakukan dengan sosialisasi lebih lanjut mengenai manfaat pemungutan serta mengenai peraturan perundang-undangan retribusi pasar yang di punggut kepada pedagang agar para pedagang bisa lebih memahami dan mengerti mengenai retribusi pasar di Kota Bitung.

2. Pemerintah dan Dinas Perdagangan Kota Bitung kedepannya lebih mempertimbangkan perhitungan penetapan target atas Retribusi Pasar pada tahun-tahun berikutnya agar tingkat keefektivitasan Retribusi Pasar tidak turun naik dan bisa tetap stabil. 


\section{DAFTAR PUSTAKA}

Mahmudi. 2015. Manajemen Kriteria Sektor Publik Edisi Ketiga. UPP STIM YKPN. Yogyakarta.

Mardiasmo. 2018. Perpajakan Edisi Terbaru. Andi Offset. Yogyakarta

Najoan, C., Harijanto, S., dan Datu, C. 2016. Analisis Sistem Pemungutan Dan Penyetoran Retribusi Pasar Pada Dinas Perindustrian Perdagangan Koperasi Dan Penanaman Modal Kotamobagu. Jurnal Emba Vol 4 (1). Universitas Sam Ratulanggi. Manado

Naleng, A., Manossoh, H., dan Tangkuman, S. J. 2017. Analisis Potensi Dan Efektivitas Pemungutan Retribusi Pasar DiKabupaten Kepulauan Siau Tagulandang Biaro. Jurnal Emba Vol 5 (2).Universitas Sam Ratulanggi. Manado

Peraturan Pemerintah Daerah Kota Bitung Nomor 4 Tahun 2011 Tentang Retribusi Jasa Umum. 2011. Bitung

Peraturan Pemerintah Daerah Kota Bitung Nomor 1 Tahun 2014 Tentang Perubahan Kedua Atas Peraturan Daerah Kota Bitung Nomor 4 Tahun 2011 Tentang Retribusi Jasa Umum. 2014. Bitung

Peraturan Pemerintah Daerah Kota Bitung Nomor 8 Tahun 2016 Tentang Pembentukan dan Susunan Perangkat Daerah Kota Bitung. 2016. Bitung

Pura, 2013. Pengantar Akuntansi 1 : Pendekatan Siklus Akuntansi. Penerbit Erlangga. Jakarta Rahardjo, A. 2011. Manajemen Pemerintah Daerah. Graha Ilmu. Yogyakarta

Surjaweni, W. 2015. Metodologi Penelitian Bisnis Dan Ekonomi. Pusat Baru Press. Yogyakarta

Undang Undang Republik Indonesia Nomor 28 Tahun 2009 Tentang Pajak Daerah Dan Retribusi Daerah. 2009. Lembaran Negara Indonesia Tahun 2009. Jakarta Waluyo. 2013. Perpajakan Indonesia Edisi Kesebelas Buku 1. Salemba Empat. Jakarta 